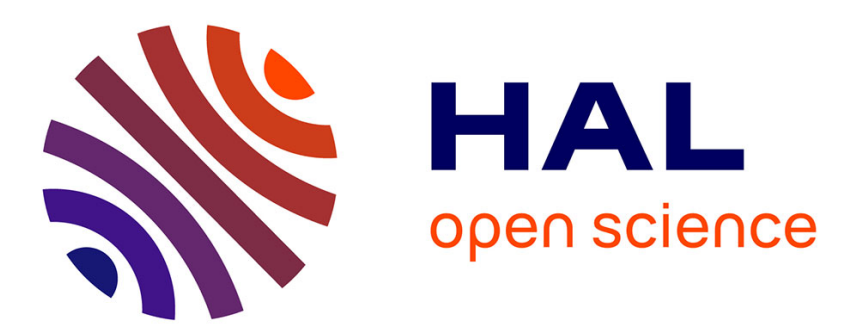

\title{
Pelecyogyra (Mollusca) from the Early Ordovician of the Montagne Noire, France
}

Jan Ove Ebbestad, Bertrand Lefebvre, Jean-Paul Kundura, Marie-Hélène Kundura

\section{- To cite this version:}

Jan Ove Ebbestad, Bertrand Lefebvre, Jean-Paul Kundura, Marie-Hélène Kundura. Pelecyogyra (Mollusca) from the Early Ordovician of the Montagne Noire, France. Geobios, 2020, 63, pp.23-32. 10.1016/j.geobios.2020.09.003 . hal-03003880

\section{HAL Id: hal-03003880 \\ https://hal.science/hal-03003880}

Submitted on 13 Nov 2020

HAL is a multi-disciplinary open access archive for the deposit and dissemination of scientific research documents, whether they are published or not. The documents may come from teaching and research institutions in France or abroad, or from public or private research centers.
L'archive ouverte pluridisciplinaire HAL, est destinée au dépôt et à la diffusion de documents scientifiques de niveau recherche, publiés ou non, émanant des établissements d'enseignement et de recherche français ou étrangers, des laboratoires publics ou privés. 


\section{Geobios}

\section{Pelecyogyra (Mollusca) from the Early Ordovician of the Montagne Noire, France --Manuscript Draft--}

\begin{tabular}{|c|c|}
\hline \multicolumn{2}{|l|}{ Manuscript Number: } \\
\hline Keywords: & $\begin{array}{l}\text { Onychochilidae; Mimospirida; Carcassonnella; Lesueurilla; Thoralispira; Fezouata } \\
\text { biota }\end{array}$ \\
\hline Corresponding Author: & $\begin{array}{l}\text { Jan Ove Ebbestad, PhD } \\
\text { Uppsala University } \\
\text { Uppsala, Sweden }\end{array}$ \\
\hline First Author: & Jan Ove Ebbestad, PhD \\
\hline \multirow[t]{3}{*}{ Order of Authors: } & Jan Ove Ebbestad, PhD \\
\hline & Bertrand Lefebvre, PhD \\
\hline & Jean-Paul Kundura \\
\hline \multirow[t]{4}{*}{ Suggested Reviewers: } & $\begin{array}{l}\text { Daniel Vizcaino, PhD } \\
\text { daniel.vizcaino@wanadoo.fr } \\
\text { He is an expert on the Montagne Noire fauna and stratigraphy }\end{array}$ \\
\hline & $\begin{array}{l}\text { Muriel Vidal, PhD } \\
\text { Universite de Bretagne Occidentale } \\
\text { muriel.vidal@univ-brest.fr } \\
\text { Dr Vidal has worked on the right stratigraphic level in both Montagne Noire and } \\
\text { Morocco }\end{array}$ \\
\hline & $\begin{array}{l}\text { Björn Kröger, PhD } \\
\text { Senior curator, Finnish Museum of Natural History } \\
\text { bjorn.kroger@helsinki.fi } \\
\text { Dr Kröger knows the stratigraphy of both Montagen Noire and Morocco and works on } \\
\text { molluscs }\end{array}$ \\
\hline & Jiri Frýda, PhD \\
\hline
\end{tabular}


Czech University of Life Sciences Prague

bellerophon@seznam.cz

Professor Frýda is a world leading expert on early molluscs

Powered by Editorial Manager ${ }^{\circledR}$ and ProduXion Manager ${ }^{\circledR}$ from Aries Systems Corporation 


\section{Pelecyogyra (Mollusca) from the Early Ordovician of the Montagne Noire, 2 France}

3

4 Jan Ove R. Ebbestad ${ }^{\mathrm{a}}$, Bertrand Lefebvre ${ }^{\mathrm{b}}$, Jean-Paul Kundura ${ }^{\mathrm{c}}$, Marie-Hélène Kundura ${ }^{\mathrm{c}}$

5

6 a Museum of Evolution, Uppsala University, Norbyvägen 16, 75236 Uppsala, Sweden

7 bLaboratoire de Géologie de Lyon, UMR CNRS 5276, bât. Géode, Université Lyon 1,

8 Campus de la Doua, 2, rue Dubois, 69622 Villeurbanne cedex, France

$9 \quad$ c13, villa du Pré, 91860 Epinay-sur-Sénart, France

10

11 Corresponding author. E-mail addresses: Jan-Ove.Ebbestad@em.uu.se,

12 joebbestad@hotmail.com (J.O.R. Ebbestad).

14 Abstract

A new occurrence of the onychochilid mollusc Pelecyogyra is reported from the late Floian

Landeyran Formation (Apatokephalus incisus Biozone) in the Montagne Noire, southern

17 France, where it is associated with the two tergomyans Carcassonnella courtessolei and

Thoralispira laevis, and a mollusc indet. with a low cap-shaped shell. Flattened specimens of

T. laevis in the same formation may be misinterpreted as specimens of Pelecyogyra.

Morphologically the Montagne Noire specimens compare with Pelecyogyra fezouataensis

21 from the late Tremadocian Fezouata Formation (Araneograptus murrayi Biozone) in

22 Morocco and are tentatively referred to this species. Each occurrence of Pelecyogyra is from 
one or two localities only, but separated in time. They differ further in the deeper facies, association with Carcassonnella and Thoralispira, and non-gregarious occurrence in Montagne Noire compared to the shallower facies, lack of other molluscs and gregarious occurrence in the Fezouata Formation. In the Lower Ordovician, Pelecyogyra,

Carcassonnella courtessolei, the rare $C$. vizcainoi and Thoralispira laevis are taxa that occur only in Montage Noire and the Anti-Atlas, while Lesueurilla prima also occurs in the Prague basin of the Czech Republic. Contrary to other faunal elements, like echinoderms and trilobites, these genera seem to have a wide environmental tolerance and are long ranging taxa. The main occurrence of the three key taxa Carcassonnella, Thoralispira and Lesueurilla in the Montagne Noire is in the lower part of the La Maurerie Formation (Taihungshania miqueli acme Zone), while the same taxa appear just slightly later in Morocco (?Cymatograptus protobalticus Biozone). Migration to the Anti-Atlas during the early Floian seems to have been possible during a period of general faunal exchange. Pelecyogyra may either have migrated from the Anti-Atlas to Montagne Noire during the same interval or possibly during the late Floian as indicated by shared faunal elements between these two regions at that time.

Keywords: Onychochilidae, Mimospirida, Carcassonnella, Lesueurilla, Thoralispira, Fezouata biota

\section{Introduction}

Pelecyogyra is a striking, large sinistrally coiled mollusc hitherto known only from the Lower Ordovician Fezouata Formation of Morocco (Ebbestad and Lefebvre, 2015). The peculiar low spired conch has three rapidly expanding whorls, a large rounded planar aperture, and a 
fairly thin shell with simple growth lines. The taxon is also the only known Tremadocian member the Family Onychochilidae Koken in Koken and Perner, 1925. All known Moroccan specimens are preserved dorso-ventrally compressed to some degree, and found originally only at Oued Beni Zoli (locality Z-F5) in the Zagora area of Central Anti-Atlas, but then also in a laterally equivalent site about $1.2 \mathrm{~km}$ to the west (Kouraïss et al., 2015). Both sites include sediments encompassing the Araneograptus murrayi graptolite Biozone (late Tremadocian). Pelecyogyra occurs with a diverse assemblage of trilobites, echinoderms and other fauna, but no other gastropods or tergomyans. Accompanying gastropod and tergomyan molluscs higher in the Fezouata succession are Carcassonnella courtessolei (Yochelson, 1982) and Thoralispira laevis (Thoral, 1935), species otherwise only found in the Montagne Noire (Horný, 1997; Ebbestad, 2016). Lesueurilla prima (Barrande in Perner, 1903) is also in common between Morocco and France, and is a taxon recognized in the Lower Ordovician and Middle Ordovician of western mid-to high latitude peri-Gondwana areas (Ebbestad, 2016; Ebbestad et al., 2016 and references therein). These three genera are here treated as signature taxa that may be helpful in understanding the faunal exchange between periGondwana areas. Recently, four specimens of Pelecyogyra were discovered in the lower part of the Landeyran Formation (late Floian) near Le Foulon in the Montagne Noire (southern France), where they occur with an abundant and relatively diverse fauna (Vizcaïno et al., 2001) (Fig. 1). This is the first occurrence of Pelecyogyra outside Morocco and the species is attributed to $P$. cf. fezouataensis Ebbestad and Lefebvre from Morocco. The age, preservation, associated fauna, and ecology differ between the two, which is discussed in this paper along with the implications for the correlation and faunal exchange with the Fezouata Formation in the Anti-Atlas of Morocco. 


\section{Geological setting and material}

The Montagne Noire, in the southern part of the highland region of Massif Central, is composed of a complex series of tectonic units and nappes (Demange, 2001). Cambrian and younger sediments are found on each side of a central area with gneisses and schists, and are divided into the northern and southern Montagne Noire areas (Fig. 1). In the southern Montagne Noire, the thick, dominantly siliciclastic Lower Ordovician succession consists of six formations (Fig. 2). The traditional levels and 'faunizones' originally defined by Courtessole et al. $(1981,1982,1985,1991)$ in this area were at best inaccurate and poorly defined because they partly reflected biofacies rather than ranges (Vizcaïno and Álvaro, 2003; Tortello et al., 2006 and references therein). A detailed biostratigraphic framework was recently established for this succession (Fig. 2), based on trilobite ranges and zones across the lithofacies (Vizcaïno and Álvaro, 2003; Tortello et al., 2006). Many of these trilobite taxa can be used for regional correlations, and in particular, with the Lower Ordovician of the AntiAtlas, Morocco (Martin et al., 2016). More traditional index taxa (e.g. acritarchs, conodonts, graptolites) are rare and/or restricted to some units, and generally in need of revision (Barrois, 1892, 1893; Thoral, 1935; Dean, 1966; Vizcaïno et al., 2001; Serpagli et al., 2007).

Specimens of Pelecyogyra were found west of Les Sources du Foulon, situated near the southern bank of the Orb river, about 1300 m east of Lugné, municipality of Cessenon-surOrb, Hérault, southern France (locality CS 34, Fig. 1). This site corresponds to locality $\lambda 32$ of Dean (1966) and CS 34 of both Babin et al. (1982, fig. 4) and Tortello et al. (2006, appendix). In the last 20 years, detailed, level by level excavations carried out in that locality by two of the authors (JPK and MHK) yielded a rich and diverse macrofauna, comprising bivalves, brachiopods, conulariids, echinoderms, graptolites, trilobites and various other taxa. The four specimens of Pelecyogyra were found in 2004, 2009 and 2012, and must be considered as rare at this site. 
The locality west of Les Sources du Foulon consists of a 10 meter thick section of homogeneous fissile mudstones, within the Apatokephalus incisus trilobite Biozone (lower part of the Landeyran Formation, late Floian; Fig. 2). Around 20 species of trilobites were recorded from this site (Dean, 1966; Vizcaïno et al., 2001; Tortello et al., 2006; Kundura, 2015). Many trilobites are preserved as entire specimens, indicative of relatively sudden burial events in otherwise quiet, distal depositional conditions (Dean, 1966). The lower part of the Landeyran Formation is considered to represent offshore, muddy deposits in a generally deepening sequence (Vizcaïno and Lefebvre, 1999; Vizcaïno et al., 2001). Detailed sampling in the site west of Les Sources du Foulon revealed a Colpocoryphe-Asaphellusas Foulonia, Niobe, Ogygiocaris, Pliomerops and Selenopeltis (Kundura, 2015).

\section{Systematic palaeontology}

112 Montagne Noire specimens described herein belong to the Kundura collection, and are deposited in the Muséum National d'Histoire naturelle, Paris, France (MNHN). The type material of Moroccan Pelecyogyra illustrated here for comparison purposes belongs to the Reboul collection, and is deposited in the Muséum d'Histoire naturelle de Marseille, France (MHNM). 
122 Remarks. Based on functional considerations Linsley and Kier (1984) established

123 Paragastropoda, a new class of presumed untorted molluscs with sinistrally coiled shells. As constructed, the class was already from the start considered paraphyletic (Linsley and Kier, 1984, p. 247). Within their Order Orthostrophina, they included the pelagilleids and within their Order Hyperstrophina, they included hyperstrophic macluritids, onychochilids, clisospirids and tentatively even euomphalids. While onychochilids and clisospirids are considered closely related (Horný, 1964; Peel, 1986), subsequent studies on protoconch development have shown that macluritids and euomphalids are not related to these and that Paragastropoda does not seem to have any zoological validity (Frýda, 1999, 2012 and references therein; Frýda and Rohr, 2006; Frýda et al., 2008), thus leaving only onychochilids and clisospirids in the original Hyperstrophina. Onychochilids and clisospirids were placed as two families in the Suborder Mimospirina by Dzik (1983), distinguished mainly by the height of the shell and the nature of the aperture, and both were united in the Superfamily Onychochiloidae Koken in Koken and Perner, 1925 (as Onychochilacea), by Linsley and Kier (1984). As pointed out in Ebbestad and Lefebvre (2015), because of the reduction of the concept of the Order Hyperstrophina (containing only the Suborder Mimospirina with Onychochilidae and Clisospiridae), Mimospirina Dzik, 1983, has priority and should be raised to the level of order. However, Bouchet et al. $(2005,2017)$ did not use Mimospirina and united the two families in the Superfamily Clisospiroidea Miller, 1889 (having priority over the Onychochiloidea), containing sinistrally coiled taxa with sinistrally coiled 142 protoconchs. They followed Knight et al. (1960) and included the Subfamily Progalerinae 143 Knight, 1956, which have a dextral shell, but a sinistral protoconch, in the Clisospiridae. 

concept of Dzik (1983), who considered these taxa to be hyperstrophic dextral gastropods (sinistral shell, dextral configuration of the body), although the sinistral coiling alone is not a proof of hyperstrophy (Yochelson, 1984; Peel and Horný, 1996; Frýda and Rohr, 2006); they could be sinistral orthostrophic taxa (sinistral shell, sinistral configuration of the body). It still leaves the question, whether these taxa were torted or untorted, i.e. gastropods or not. Ebbestad and Lefebvre (2015) placed the new genus Pelecyogyra in the Family

Onychochilidae within the class Paragastropoda Linsley and Kier, 1984, tacitly considering it as an untorted mollusc. However, the umbilical side and nature of the aperture is unknown in this genus, which does not allow a detailed appreciation of the functional morphology. Members of the Onychochilidae are broadly accepted today as gastropods (Bouchet et al., 2005, 2017; Frýda, 2012), although not within the Archaeogastropoda (Frýda, 1999, 2001, 2012). A broader analysis of the numerous and disparate members of this group (see Fryda and Rohr, 1999; Ebbestad and Lefebvre, 2015, table 1) may shed light on this problem. Nevertheless, as a consequence of morphological uncertainties and the eroded concept of the Paragastropoda, the previous opinion on Pelecyogyra by Ebbestad and Lefebvre (2015) is reconsidered and the placement of the genus within Onychochilidae as a gastropod is followed herein, adhering to the classification in Bouchet et al. $(2005,2017)$. The inclusion of Cambrian pelagiellids in the class Pargastropoda by Linsley and Kier (1984) and its implications is not considered herein, as this is an entirely different discussion. 
167 Type species: By monotypy, Pelecyogyra fezouataensis Ebbestad and Lefebvre, 2015, p.

430, figs 3-5, from the Lower Ordovician, late Tremadocian Araneograptus murrayi graptolite Zone, Fezouata Formation, at the Quaternary terrace of Oued Beni Zoli (Z-F5), west of Jbel Bou- Dehir, about $17 \mathrm{~km} \mathrm{~N}$ of Zagora, in central Anti-Atlas, Morocco.

Pelecyogyra cf. fezouataensis Ebbestad and Lefebvre, 2015

Figs 3B, 4A-J

Locality and horizon: West of Les Sources du Foulon, Cessenon-sur-Orb municipality, Hérault, southern France, Apatokephalus incisus trilobite Biozone, lower part of the Landeyran Formation (late Floian).

Material: Four specimens (Kundura collection, MNHN.F.A71806- MNHN.F.A71809), mostly preserved as tectonically deformed internal moulds. One specimen (MNHN.F.A71808) retains patches of shell.

Remarks: Although the Le Foulon specimens are slightly deformed and poorly preserved they can be compared closely with Pelecyogyra fezouataensis from Morocco (Fig. 3A). This taxon was recently described by Ebbestad and Lefebvre (2015), and although a redescription is not needed some features of the Montagne Noire specimens are highlighted for comparison. The largest specimen (MNHN.F.A71808, Figs 3B, 4F) is about $2 \mathrm{~cm}$ wide, compared to the maximum $2.7 \mathrm{~cm}$ of the Moroccan material. This largest Montagne Noire specimen is however tectonically shortened and it would have originally approached the size 
of the largest Moroccan individual (see also Fig. 4I). Shell patches in MNHN.F.A71808 appear wrinkled, as seen also in Moroccan specimens, but the fine growth lines cannot be seen in the Le Foulon specimens (Fig. 4H). Similarly, the irregular bands preserved on internal moulds of Moroccan specimens are not present in the French specimens (Fig. 4A, D, E). In both Le Foulon and Oued Beni Zoli specimens, the similar shape and large size of the protoconch suggest that larvae were non-planktotrophic. Although dorso-ventrally flattened, specimen MNHN.F.A71806 shows some degree of the curvature of the shell in both the penultimate and last whorl (Fig. 4B, C). The edge of the aperture is flat to the sediment, with a small marginal edge on the internal mould. This compares well with the Moroccan species (compare Fig. 4A, D, E with Ebbestad and Lefebvre, 2015, fig. 3B).

The Moroccan Pelecyogyra fezouataensis was originally known from more than 50 specimens, all from the same locality. The fossils are generally well-preserved and undisturbed by tectonics. Typically several specimens occur together and a certain range in size is evident. A size range is also evident for the Montagne Noire specimens. However, they do not show evidence of being gregarious, which could be related either to their rarity or lack of sorting and transport in the deeper water setting. They also differ from Moroccan specimens in co-occurring with specimens of Carcassonnella courtessolei and Thoralispira laevis (Fig. 4J, 5D) (see also sample list in Horný and Vizcaïno, 1995, p. 39).

Another hitherto undescribed taxon from the Montagne Noire also occurs in the Landeyran Formation at the Le Foulon site (Fig. 5E, F). It has a low cap-shaped shell, where the sloping side has been pushed inwards and deformed the fossil. Maximum width of an undeformed specimen would be around $10 \mathrm{~mm}$. The aperture is planar and with a broadly circular outline. The pointed apex projects a bit, but does not overhang the margin of the shell, with a subapical surface that curves sharply towards the margin. Preservation does not allow a precise determination of this specimen, nor is it possible to determine whether it is a 
gastropod or a tergomyan mollusc. Yochelson (1982) described two broadly similar taxa from the La Maurerie Formation as Archinacella sp. and A. cf. A. ovata Barrande in Perner, 1903 (now Barrandicella Peel and Horný, 1999), but those have an apex closer to or overhanging the margin. Horný (1995) described the enigmatic cap-shaped mollusc Solandangella from the Foulon Formation, but this differs from the younger cap-shaped specimen from Le Foulon in being larger, having a more sub-central and less pointed apex with a less inclined apical slope. The internal mould of Solandangella possesses a distinct muscle-scar pattern, but muscle scars are not preserved in the Le Foulon indet. specimen. Two specimens of Carcassonnella courtessolei are found in close association, next to the indet. specimen (Fig. 5B). cm across, is preserved in shale at Les Rocs Nègres (locality CV 12, Fig. 1), in the upper part of the Landeyran Formation (Hanghungolithus primitivus trilobite Biozone). This being a tergomyan mollusc, where the aperture is taken to be posterior, it is the left lateral side that is preserved (Fig. 5C). Fine comarginal growth lines are visible on the surface, curving slightly abaperturally towards the dorsal part of the shell; the median dorsum itself is not preserved. Horný and Vizcaïno (1995) erected the genus based on abundant material in the Montagne Noire area, ranging from the Saint-Chinian through to the Landeyran formations. Specimens, such as the one shown herein, are rare in shales, but common in concretions in the lower half of the Landeyran Formation (Horný and Vizcaïno, 1995). The flattened left lateral side of the shell broadly resembles the shell of Pelecyogyra, albeit coiling the wrong way. However, flattened specimens of Thoralispira preserved with their right lateral side could potentially be misidentified as Pelecyogyra. Specimens tentatively identified as Carcassonnella 
courtessolei occur at Les Rocs Nègres locality (JPK pers. obs.) and probably represent the youngest documented occurrence of $C$. courtessolei in the Montagne Noire.

\section{Discussion}

4.1. Gastropods and tergomyans in the Lower Ordovician of the Montagne Noire and the Anti-Atlas

Modern descriptions of gastropod and tergomyan molluscs from the Montagne Noire were given by Yochelson (1982), Horný and Vizcaïno (1995) and Horný and Peel (1996). They range from the Saint-Chinian Formation through to the Landeyran Formation. With the addition of Pelecyogyra and the undetermined cap-shaped shell mentioned herein, 16 gastropod or tergomyan taxa are known (Fig. 2). Carcassonnella courtessolei and Thoralispira laevis are the dominant taxa throughout the entire succession, co-occurring in the lowest part with the widely distributed Peelerophon oehlerti (Bergeron, 1889).

Thoralispira sp. occurs in sandstone levels of the Cluse de l'Orb Formation, while other molluscs of the Taihungshania shui landeyranensis trilobite Biozone are found in the shaly sequence of the Setso Shale. Lesueurilla prima also has a long, though discontinuous, range, extending from the La Maurerie Formation to the Landeyran Formation. In the lower part of its range, it co-occurs with the rare, but distinct Carcassonnella vizcainoi Horný and Peel, 1996, as well as with $C$. courtessolei and T. laevis. Associated fauna places these occurrences in the Taihungshania miqueli acme trilobite Zone (Babin et al., 1982, table 1). This interval shows the highest diversity of gastropods and tergomyans in the Lower Ordovician of the Montagne Noire (Fig. 2). 
Pelecyogyra occurs in the Landeyran Formation (Apatokephalus incisus Zone) in the upper part of the succession, associated with both C. courtessolei and T. laevis. The entire succession in which these molluscs range is nearly $1300 \mathrm{~m}$ thick, covering the latest Tremadocian and the Floian, which gives a very long range for some of the key taxa. Most of the occurrences discussed herein are associated with calm, distal settings typical of the raphiophorid biofacies (Saint-Chinian Formation, base of the La Maurerie Formation and the Landeyran Formation), as shown by the occurrence of Ampyx priscus. On the other hand, the presence of these mollusks also in the shallower, more proximal settings of both the Cluse de l'Orb and Foulon formations (where raphiophorids are absent, and more proximal trilobite assemblages are occurring) does not support any close relationship between these taxa and any particular sedimentary setting, bathymetry or trilobite biofacies.

The distribution of gastropods and tergomyans in the Lower Ordovician Fezouata Formation of Anti-atlas, Morocco is in many respects similar to that in the Montagne Noire (Horný, 1997; Ebbestad, 2016), although the range of the three key taxa Carcassonnella, Thoralispira and Lesueurilla differs and are much more restricted in the Anti-Atlas area (Fig. 2). The hitherto recognized diversity in the Anti-Atlas is as well lower, with only seven species known (Fig. 2). The distribution pattern seen in the Anti-Atlas may be affected either by environmental conditions and/or sampling bias.

A large number of specimens of T. laevis are known from various localities of the Fezouata Formation (Horný, 1997; Ebbestad, 2016). For occurrences of Thoralispira, Horný (1997) listed Destombes localities 34, 983, 1540, 1572, 1621 and 1682, of which the first was equalled to locality F-Z26 in Ebbestad (2016) within the ?Cymatograptus protobalticus graptolite Biozone. It would mean an increased range downwards of this taxon, not reflected in Ebbestad (2016, fig. 2), where only stratigraphically constrained specimens from locality Z-F25 were included. Both C. courtessolei and L. prima are associated with T. laevis at these 
localities (Horný 1997). However, the various Destombes localities are far apart and difficult to date, although associated fauna suggest a Floian age for all of them. The age uncertainty is reflected in Fig. 2, where tentative extended ranges upwards for the three key taxa are indicated.

The confirmed extended range downwards of T. laevis is plotted in Fig. 2 herein, thus matching those of taxa $C$. courtessolei, C. vizcainoi and L. prima within the ?Cymatograptus protobalticus graptolite Biozone. The occurrence of C. vizcainoi Horný and Peel, 1996 at locality Z-F26 (Ebbestad 2016), may be of importance as it has a restricted occurrence in Montagne Noire (Horný and Peel, 1996), while the three key taxa extend also up into the ?Baltograptus jacksoni Zone and possibly higher. Peelerophon would be expected in the Fezouata Formation but has not yet been recognized. Pelecyogyra occurs stratigraphically low in the unit, and is not found with other gastropods or tergomyans. The entire succession in which these molluscs range is about $370 \mathrm{~m}$ thick, and the associated trilobite assemblage, including taxa like Ampyx priscus and Colpocoryphe, reflects the distal raphiophorid biofacies (Martin et al., 2016).

4.2. Correlation between Montagne Noire and the Anti-Atlas area

In the Lower Ordovician, Pelecyogyra, Carcassonnella courtessolei, C. vizcainoi and Thoralispira laevis are taxa that only are reported from Montage Noire and the Fezouata Formation in the Anti-Atlas, while Lesueurilla prima also occurs in the Prague basin of the Czech Republic and the Middle Ordovician of Iran (Ebbestad et al., 2016). These key taxa are therefore potentially of interest to understand the correlation and faunal exchange between the two areas in the Lower Ordovician. 
310 Gastropod or tergomyan molluscs have been collected from the middle Tremadocian La

311 Dentelle Formation (JPK, pers. obs.), but the stratigraphically oldest Ordovician gastropod

312 and tergomyan molluscs identified in the literature in the Montagne Noire appear in the

313 Euloma filacovi trilobite Biozone in the Saint-Chinian Formation. Tremadocian conodonts of

314 the Paltodus deltifer deltifer conodont Subzone are known in the lower part of the underlying

315 Shumardia (C.) pusilla trilobite Biozone (Álvaro et al., 2007; Serpagli et al., 2007). This zone

316 is just below the A. murrayi graptolite Biozone (Bergström et al., 2004), where Pelecyogyra

317 is found in the Fezouata Formation, and according to Fortey (2011) zonal graptolites of this

318 type occur in the upper Saint-Chinian Formation in France. In both known Moroccan

319 occurrences, Pelecyogyra is abundant but without associated remains of the other key

320 mollusc taxa.

321 Fortey (2011) also reported Tetragraptus akzharensis from the Taihungshania miqueli acme

322 trilobite Zone in Montagne Noire, a species associated with the upper subdivision of $T$.

323 phyllograptoides graptolite Biozone (Bergström et al., 2004). The lower part of the Upper

324 Fezouata Formation encompass the ?Cymatograptus protobalticus graptolite Biozone, also corresponding to the upper subzone of the T. phyllograptoides graptolite Biozone (Bergström et al., 2004). Thus, the main co-occurrence of C. courtessolei, C. vizcainoi (rare), T. laevis, and L. prima at the base of the $\sim 400 \mathrm{~m}$ thick La Maurerie Formation and within the Taihungshania miqueli acme trilobite Zone, appears close to that of the lower range of these molluscs in the Upper Fezouata Formation, in the ?Cymatograptus protobalticus graptolite Biozone, although the Moroccan occurrences seem a bit younger.

The zonal fossil Taihungshania in Montagne Noire is absent in the Fezouata Formation, which suggests that faunal exchanges with this part of Morocco were restricted at least until the latest Tremadocian (Martin et al., 2016). This is also reflected in a high relative endemicity of both echinoderms and trilobites in the shallower depositional settings of the 
late Tremadocian (Lefebvre et al., 2016; Martin et al., 2016). In contrast, endemicity of echinoderms and trilobites is lower in the early Floian, coinciding with a general transgressive trend and deeper facies (Lefebvre et al., 2016; Martin et al., 2016). This interval is also where the main distribution of gastropod and tergomyan molluscs is found (Fig. 2). The trilobite assemblage, including taxa like Ampyx priscus and Colpocoryphe, reflects the raphiophorid biofacies (Martin et al., 2016).

It seems that $C$. courtessolei, L. prima and T. laevis had a relatively wide environmental tolerance as they are found across a range of biofacies in the Montagne Noire. Environmental preferences is clearer for e.g. trilobites and echinoderms, with some taxa restricted to the distal raphiophorid biofacies in the Saint-Chinian and La Maurerie formations, then absent in the shallower Cluse de l'Orb and Foulon formations, and re-appearing again in the Landeyran Formation, with the return of more distal conditions (raphiophorid biofacies; Vizcaïno and Lefebvre, 1999). Such a pattern is absent for the three key taxa in Montagne Noire, but a wider environmental tolerance would on the other hand facilitate faunal exchange to the AntiAtlas area during the early Floian. Thus, although the main occurrences of the key taxa coincide fairly well between Montagne Noire and Morocco it probably reflects a temporary breakdown of faunal barriers and migration of faunas during an opportune time between the two areas. As the key taxa have long ranges, their biostratigraphical value seems otherwise limited.

Some associated trilobites (Martin et al., 2016), echinoderms (Vizcaïno and Lefebvre, 1999; Lefebvre et al., 2016) and bivalves (Babin, 1982; Polechová, 2016) from the ?Baltograptus jacksoni graptolite Biozone in the Fezouata Formation are as well found in the Landeyran Formation in Montagne Noire (see also discussion in Lefebvre et al., 2018), but Martin et al. (2016) suggested that the trilobite assemblage in Morocco was slightly older than that of the Landeyran Formation. The graptolite assemblage in the lower Landeyran 
Formation belongs with the Pseudophyllograptus densus graptolite Biozone (GutiérrezMarco in Kröger and Evans, 2011), presently correlated with the late Floian Baltograptus minutus graptolite Biozone (Gutiérrez-Marco and Martin, 2016), which supports the slight differences in ages.

All four specimens of Pelecyogyra cf. fezouataensis from Montagne Noire come from the same locality and are well-constrained by trilobites to the Apatokephalus incisus trilobite Biozone. Graptolites at this site suggest a placement within the Baltograptus minutus graptolite Biozone, thus establishing a late Floian age. The depositional setting represents quiet muddy deposits in an off-shore environment within a raphiophorid biofacis.

In Morocco Pelecyogyra fezouataensis occurs at Oued Beni Zoli (locality Z-F5) and the species was also found at a laterally equivalent site $1.2 \mathrm{~km}$ to the west. The sections there contain a high diversity assemblage commonly associated with younger strata in the Fezouata area, which lead Kröger and Lefebvre (2012) to suggest an early Floian age. This would be equivalent to sections yielding Carcassonnella courtessolei, C. vizcainoi, Lesueurilla prima and Thoralispira laevis (localities Z-F24 (north of Toumiat) and Z-F26 (Toumiat), of the ?Cymatograptus protobalticus graptolite Zone, see fig. 2 in Ebbestad and Lefebvre, 2015), in slightly deeper facies. However, the apparent similarities of the assemblages is attributed to similar environmental settings, and the Z-F5 locality and the lateral equivalent represent the late Tremadocian ( $\operatorname{Tr} 3)$ Araneograptus murrayi graptolite Biozone in well-oxygenated lower shoreface environments (Kouraiss et al., 2015; Martin et al., 2016). The Fezouata specimens are often aligned in the troughs of ripple marks (Ebbestad, 2016) testifying to the shallower settings. 
The single occurrences of Pelecyogyra allow no appreciation of the range of the genus in either area, but besides the large time span between them there are some significant differences in the two occurrences. They differ in the deeper facies, association with Carcassonnella and Thoralispira, and non-gregarious association in Montagne Noire compared to the shallower facies, lack of other molluscs and gregarious association in the Fezouata Formation. Key mollusc taxa in Montagne Noire and the Fezouata Shale have a relatively long range, as do several species of trilobites (Martin et al., 2016). But whereas e.g. the trilobite assemblages clearly define environmental settings in both areas (Vizcaïno and Álvaro, 2003; Martin et al., 2016) the molluscs in Montagne Noire range across both distal and proximal sedimentary settings; the range in the Anti Atlas as currently known is much more restricted. Migration of these taxa from the Montagne Noire area may have occurred during a short-lived opportune dispersal of marginal raphiophorid assemblages during times of deeper facies distribution in the early Floian as discussed earlier.

Pelecyogyra may represent a taxon endemic to the Anti-Atlas area in the late Tremadocian, only able to migrate outside the area during the Floian. A large protoconch suggests that Pelecyogyra had non-plankotrophic larvae, generally associated with dispersal only over short distances, but if the taxon had a wide environmental tolerance a wide dispersal would not necessarily be precluded by a non-planktotrophic larval development (see for instance Hansen, 1980; Jablonski and Roy, 2003 and references therein). It may further suggest that the Montagne Noire specimens represent a distinct species through adaptive divergence, although there are no apomorphic features to support this notion.

The exact timing of the dispersal remains unsettled, as it is possible that Pelecyogyra either migrated to Montagne Noire from Morocco in the early Floian or arrived much later.

407 The deeper facies and common occurrence of trilobite species between the older strata in Morocco and the younger Landeyran Formation in Montagne Noire, could support a late 
dispersal from Morocco during a transgressive phase. In that case, more occurrences of Pelecyogyra could be expected in the early and middle Floian of Morocco but not in

411 Montagne Noire. On the other hand, if the dispersal occurred already in the early Floian,

412 when the three key taxa Carcassonnella, Thoralispira and Lesueurilla appear in Morocco, 413 Pelecyogyra would be expected to occur even in the early and middle Floian in Montagne 414 Noire. It is also a clear distance between these regions of the Gondwana margin, if the tentative palaeogeographic reconstruction in Álvaro et al. (2003) is considered, which may suggest that Pelecyogyra could be expected to be found in regions that were in between the Anti Atlas and Montagne Noire during the Lower Ordovician. Only further finds of the genus may clarify this problem.

Acknowledgements

J.C. Gutiérrez-Marco, Madrid, provided valuable comments on an initial draft of this manuscript. This paper is a contribution to the International Geoscience Programme (IGCP) Project 653 - The onset of the Great Ordovician Biodiversification Event.

References

Álvaro, J.J., Elicki, O., Geyer, G., Rushton, A.W.A., Shergold, J.H., 2003.

427 Palaeogeographical controls on the Cambrian trilobite immigration and evolutionary patterns reported in the western Gondwana margin. Palaeogeography, Palaeoclimatology, Palaeoecology 195, 5-35. 
Álvaro, J.J., Ferretti, A., González-Gómez, Serpagli, E., Tortello, M.F., Vecoli, M., Vizcaïno, D., 2007. A review of the Late Cambrian (Furongian) palaeogeography in the western Mediterranean region, NW Gondwana. Earth-Science Reviews 85, 47-81.

Babin, C., 1982. Mollusques bivalves et rostroconches, in: Babin, C., Courtessole, R., Melou, M., Pillet, J., Vizcaïno, D., Yochelson, E.L. (Eds.), Brachiopodes (Articules) et Mollusques (Bivalves, Rostroconches, Monoplacophores, Gastropodes) de l'Ordovicien inferieur (Tremadocien-Arenigien) de la Montagne Noire (France meridionale). Mémoire de la Société des Etudes Scientifiques de l'Aude, 1982, 63 pp.

Barrois, C., 1892. Mémoire sur la distribution des Graptolites en France. Annales de la Société Géologique du Nord 20, 75-191.

Barrois, C., 1893. Sur le Rouvilligraptus Richardsoni de Cabrières. Annales de la Société Géologique du Nord 21, 107-112.

Bergeron, J., 1889. Étude géologique du massif ancien situé au Sud du plateau central. G. Masson, Paris, 362 pp.

Bergström, S.M., Löfgren, A., Maletz, J., 2004. The GSSP of the second (Upper) stage of the Lower Ordovician series: Diabasbrottet at Hunneberg, province of Vastergotland, southwestern Sweden. Episodes 27, 265-272.

Bouchet, P., Rocroi, J.-P., Frýda, J., Hausdorf, B., Ponder, W., Valdes, A.,Warén, A., 2005. Classification and nomenclator of gastropod families. Malacologia 47, 1-368.

Bouchet, P., Rocroi, J.-P., Hausdorf, B., Kaim, A., Kano, Y., Nützel, A., Parkhaev, P., Schrödl, M., Strong, E.E., 2017. Revised classification, nomenclator and typification of gastropod and monoplacophoran families. Malacologia 61, 1-526. 
452 Courtessole, R., Henry, J.L., Vizcaïno, D., 1991. Quelques Calymenidae (Trilobita) de

453 l'Ordovicien inférieur (Arénig) de la Montagne Noire, France: systématique, évolution et 454 paléoenvironnements. Palaeontographica, Abteilung A 218, 1-15.

455 Courtessole, R., Pillet, J., Vizcaïno, D., 1981. Nouvelles données sur la biostratigraphie de 456 l'Ordovicien inférieur de la Montagne Noire. Révision des Taihungshaniidae, de 457 Megistaspis (Ekeraspis) et d'Asaphopsoides (Trilobites). Mémoire de la Société des Etudes 458 Scientifiques de l'Aude, 1-32.

459 Courtessole, R., Pillet, J., Vizcaïno, D., 1982. Aperçu stratigraphique, in: Babin, C., 460 Courtessole, R., Melou, M., Pillet, J., Vizcaïno, D., Yochelson, E.1. (Eds.), Brachiopodes 461 (Articulés) et Mollusques (Bivalves, Rostroconches, Monoplacophores, Gastropodes) de 462 l'Ordovicien inférieur (Trémadocien-Arenigien) de la Montagne Noire (France méridionale). Mémoire de la Société des Etudes Scientifiques de l'Aude, 1982, 7-22.

Courtessole, R., Pillet, J., Vizcaïno, D., Eschard, R., 1985. Etude biostratigraphique et sédimentologique des formations arénacées de l'Arenigien du Saint-Chinianais oriental (Hérault), versant sud de la Montagne Noire (France méridionale). Mémoire de la Société des Etudes Scientifiques de l'Aude, 1-99.

Cuvier, G., 1797. Tableau élémentaire de l'histoire naturelle des animaux. Baudouin, Paris, 710 pp.

Dean, W., 1966. The Lower Ordovician stratigraphy and trilobites of the Landeyran valley and the neighbouring district of the Montagne Noire, south-western France. Bulletin of the British Museum (Natural History) Geology 12, 245-353.

Demange, M., 2001. Tectonostratigraphic setting of the Minervois and Pardaihan nappes, southern Montagne Noire, in Vizcaïno, D., Álvaro, J.J. (Eds.), The Cambrian and Lower 
475 Ordovician of the southern Montagne Noire: A synthesis for the beginning of the new 476 century. Annales de la Société Géologique du Nord (2e série) 8, 191-200.

477 Dzik, J., 1983. Larval development and relationships of Mimospira - a presumably

478 hyperstrophic Ordovician gastropod. Geologiska Föreningens i Stockholm Förhandlingar $479 \quad 104,231-239$.

480

481

482

483

484

485

486

487

488

489

490

491

492

493

494

495

496

Ebbestad, J.O.R., 2016. Gastropoda, Tergomya and Paragastropoda (Mollusca) from the Lower Ordovician Fezouata Formation, Morocco. Palaeogeography, Palaeoclimatology, Palaeoecology 460, 87-96.

Ebbestad, J.O.R., Lefebvre, B., 2015. An unusual onychochilid mollusc from the Ordovician (Tremadocian) Fezouata Formation, Morocco. Geobios 48, 427-438.

Ebbestad, J.O.R., Ghobadi Pour, M., Bassett, M.G., Popov, L., 2016. First occurrence of Lesueurilla prima (Gastropoda) from the Middle Ordovician (Darriwilian) of Iran. GFF $138,510-518$.

Frýda, J., 1999. Higher classification of Paleozoic gastropods inferred from their early shell ontogeny. Journal of the Czech Geological Society 44, 137-152.

Frýda, J., 2001. Discovery of a larval shell in Middle Paleozoic subulitoidean gastropods with description of two new species from the early Devonian of Bohemia. Bulletin of the Czech Geological Survey 76, 29-37.

Frýda, J., 2012. Phylogeny of Paleozoic gastropods inferred from their morphology, in: Talent, J. (Ed.), Earth and Life: Global Biodiversity, Extinction Intervals and Biogeographic Perturbations through Time, XXXII, Springer Legacy Series, Berlin, 395435. 
497

498

499

500

501

502

503

504

505

506

507

508

509

510

511

512

513

514

515

516 517 Narodniho muzea v Praze. Oddil přirodovědny 133, 211-216.

Frýda, J., Rohr, D.M., 1999. Taxonomy and Paleobiogeography of the Ordovician Clisospiridae and Onychochilidae (Mollusca). Acta Universitatis Carolinae. Geologica 43, $405-408$.

Frýda, J., Rohr, D.M., 2006. Shell heterostrophy in early Ordovician Macluritella Kirk, 1927, and its implications for phylogeny and classification of Macluritoidea (Gastropoda). Journal of Paleontology 80, 264-271.

Frýda, J., Nützel, A., Wagner, P., 2008. Paleozoic gastropoda, in: Ponder, W.F., Lindberg, D.R. (Eds.), Phylogeny and evolution of the Mollusca. University of California Press, Berkeley, 239-270.

Fortey, R.A., 2011. A critical graptolite correlation into the Lower Ordovician of Gondwana. Proceeding of the Yorkshire Geological Society 58, 223-226.

Guérangé-Lozes, J., Burg, J.-P., 1990. Les nappes varisques du sud-ouest du Massif central (cartes géologiques et structurales à 1/250 000 Montpellier et Aurillac). Géologie de la France 3-4, 1990, 71-106.

Gutiérrez-Marco, J.C., Martin, E.L.O., 2016. Biostratigraphy and palaeoecology of Lower Ordovician graptolites from the Fezouata Shale (Moroccan Anti-Atlas). Palaeogeography, Palaeoclimatology, Palaeoecology 460, 35-49.

Hansen, T.A., 1980. Influence of larval dispersal and geographic distribution on species longevity in neogastropods. Paleobiology 6, 193-207.

Horný, R.J., 1964. New Lower Paleozoic gastropod genera of Bohemia (Mollusca). Časopis 
Horný, R.J., 1995. Solandangella gen. n., a problematic Lower Ordovician mollusc from the Montagne Noire, southern France. Acta musei Nationalis Pragae, Series B, Historia Naturalis 50, 1-11.

Horný, R.J., 1997. Ordovician Tergomya and Gastropoda (Mollusca) of the Anti-Atlas (Morocco). Sbornik Národního muzea B53, 37-78.

Horný, R.J., Peel, J.S., 1996. Carcassonnella, a new Lower Ordovician bellerophontiform mollusc with dorsally located retractor muscle attachments (Class Tergomya). Věstnik Českého Geologického Ústavu 71, 305-331.

Horný, R.J., Vizcaïno, D., 1995. Thoralispira, a new Lower Ordovician cyrtonellid genus (Mollusca,Tergomya) from the Montagne Noire, southern France. Věstnik Českého Geologického Ústavu 70, 25-41.

Jablonski, D., Roy, K., 2003. Geographical range and speciation in fossil and living molluscs. Proceedings of the Royal Society of London B 270, 401-406.

Koken, E., Perner, J., 1925. Die Gastropoden des baltischen Untersilurs. Mémoires de l'Académie des sciences de Russie. 8e série, Classe physico-mathématique 37, I-VII, 1326.

Knight, J.B., 1956. New families of Gastropoda. Journal of the Washington Academy of Sciences 46, 41-42.

Knight, J.B., Cox, L.R., Keen, A.M., Batten, R.L., Yochelson, E.L., Robertson, R., 1960. Systematic descriptions, in: Moore, R.C. (Ed.), Treatise on Invertebrate Paleontology, Part I, Mollusca 1. Geological Society of America and University of Kansas Press, Lawrence, I169-I324. 
540 Kouraïss, K., Martin, E., Lefebvre, B., Vidal, M., Gutierrez-Marco, J. C., El Hariri, K., Hafid 541 A., Bachnou, A., Azizi, A., 2015. An unusual, high-diversity assemblage in the A. murrayi 542 Zone (Late Tremadocian, Early Ordovician) of the Zagora area (Central Anti-Atlas, 543 Morocco). The Rise of Animal Life - Promoting Geological Heritage: Challenges and 544 Issues. Marrakesh 05-10th October 2015, Cadi Ayyad University, Marrakesh, 102.

545 Kröger, B., Evans, D. H., 2011. Review and palaeoecological analysis of the late 546 Tremadocian-early Floian (Early Ordovician) cephalopod fauna of the Montagne Noire, $547 \quad$ France. Fossil Record 14, 5-34.

548 Kröger, B., Lefebvre, B., 2012. Palaeogeography and palaeoecology of early Floian (Early 549 Ordovician) cephalopods from the Upper Fezouata Formation, Anti-Atlas, Morocco. $550 \quad$ Fossil Record 15, 61-75.

Kundura, J.-P., 2015. Trilobite assemblages of the Landeyran Formation (Floian), Montagne Noire, France: biostratigraphy and palaeoenvironmental implications. The Rise of Animal Life - Promoting Geological Heritage: Challenges and Issues. Marrakesh 5-10th October 2015, Cadi Ayyad University, Marrakesh, 59.

Lefebvre B., Allaire N., Guensburg T.E., Hunter A.W., Kouraïss K., Martin E.L.O., Nardin E., Noailles F., Pittet B., Sumrall C.D., Zamora S., 2016. Palaeoecological aspects of the diversification of echinoderms in the Lower Ordovician of central Anti-Atlas, Morocco. Palaeogeography, Palaeoclimatology, Palaeoecology 460, 97-121.

Lefebvre, B., Gutiérrez-Marco, J.C., Lehnert, O., Martin, E.L.O., Nowak, H., Akodad M., El Hariri, K., Servais, T., 2018. Age calibration of the Lower Ordovician Fezouata Lagerstätte, Morocco. Lethaia 51, 296-311.

Linsley, R.M., Kier, W.M., 1984. The Paragastropoda: a proposal for a new class of Paleozoic Mollusca. Malacologia 25, 241-254. 
Martin, E.L.O., Vidal, M., Vizcaïno, D., Vaucher, R., Sanjofre, P., Lefebvre, B., Destombes, J., 2016. Biostratigraphic and palaeoenvironmental controls on the trilobite associations from the Lower Ordovician Fezouata Shale of the central Anti-Atlas, Morocco. Palaeogeography, Palaeoclimatology, Palaeoecology 460, 142-154.

Miller, S.A., 1889. North American geology and palaeontology for the use of amateurs, students and scientists. Western Methodist Book Concern, Cincinnati, Ohio, 664 pp.

Peel, J.S., 1986. Systematics and mode of life of a new Silurian Clisospira (Mollusca) from North Greenland. Rapport Grønlands geologiske Undersøgelse 128, 65-74.

Peel, J.S., Horný, R.J., 1996. Sinistral hyperstrophic coiling in a Devonian gastropod from Bohemia with an in situ operculum. Palaeontology 39, 709-718.

Peel, J.S., Horný, R.J., 1999. Muscle scars and systematic position of the Lower Palaeozoic limpets Archinacella and Barrandicella gen. n. (Mollusca). Journal of the Czech Geological Society 44, 97-115.

Perner, J., 1903. Gastéropodes, in: Barrande, J. (Ed.), Système Silurien du centre de la Bohême 4(1). Charles Bellmann, Prague, XI, 164 pp.

Polechová, M., 2016. The bivalve fauna from the Fezouata Formation (Lower Ordovician) of Morocco and its significance for palaeobiogeography, palaeoecology and early diversification of bivalves. Palaeogeography, Palaeoclimatology, Palaeoecology 460, 155169.

Serpagli, E., Feretti, A., Vizcaïno, D., Álvaros, J.J., 2007. A new Early Ordovician conodont genus from southern Montagne Noire, France. Palaeontology 50, 1447-1457. 
Thoral, M., 1935. Contribution à l'étude paléontologique de I'Ordovicien inférieur de la Montagne Noire et révision sommaire de la faune cambrienne de la Montagne Noire. Imprimerie de la Charité, Montpellier, 362 pp.

Tortello, M.F., Vizcaïno, D., Álvaro, J.J., 2006. Early Ordovician agnostoid trilobites from southern Montagne Noire, France. Journal of Paleontology 80, 477-495.

Vizcaïno, D., Álvaro, J.J., 2003. Adequacy of the Lower Ordovician trilobite record in the southern Montagne Noire (France): biases for biodiversity documentation. Transactions of the Royal Society of Edinburgh: Earth Sciences 93, 393-401.

Vizcaïno, D., Lefebvre, B., 1999. Les échinodermes du Paléozoïque inférieur de Montagne Noire: Biostratigraphie et paléodiversité. Geobios 32, 353-364.

Vizcaïno, D., Álvaro, J.J., Lefebvre, B., 2001. The Lower Ordovician of the southern Montagne Noire, in Vizcaïno, D., Álvaro, J.J. (Eds.), The Cambrian and lower Ordovician of the southern Montagne Noire: A synthesis for the beginning of the new century. Annales de la Société Géologique du Nord (2e série) 8, 213-220.

Yochelson, E.L., 1982. Mollusques, Monoplacophores and Gastropodes, in: Babin, C., Courtessole, R., Melou, M., Pillet, J., Vizcaïno, D., Yochelson, E.l. (Eds.), Brachiopodes (Articulés) et Mollusques (Bivalves, Rostroconches, Monoplacophores, Gastropodes) de l'Ordovicien inférieur (Trémadocien-Arenigien) de la Montagne Noire (France méridionale). Mémoire de la Société des Etudes Scirntifiques de l'Aude, 1982, 51-59.

Yochelson, E.L., 1984. Historic and current considerations for revision of Paleozoic gastropod classification. Journal of Paleontology 58, 259-269.

\section{Figure captions}


Fig. 1. Geographical and geological maps. A. Map showing the position of Montagne Noire in southern France. B. Geological map of the southern Montagne Noire, with simplified outcrop areas of Cambrian-Devonian sediments. C. Map showing localities discussed in this paper: west of Les Sources du Foulon (CS 34) and Les Rocs Nègres (CV 12). Map in B modified from Guérangé-Lozes and Burg (1990).

Fig. 2. Stratigraphy and ranges of known gastropod and tergomyan molluscs in the Lower Ordovician of Montagne Noire, France (left) and the Fezouata Formation, Morocco (right). Grey areas in the stratigraphical column from Montagne Noire represent sandstone dominated units. Stippled upper range bars for Carcassonnella indicate tentative identification. The light grey horizontal band indicates the correlation discussed in the text. Modified from Vizcaïno and Álvaro (2003) with new data added here. The right column is modified from Ebbestad and Lefebvre (2015). Note that some biostratigraphic boundaries are placed lower compared to the lithostratigraphic column as there were some minor drafting problems with the main stratigraphical figure in Vizcaïno and Álvaro (2003, fig. 2) (pers. comm. Vizcaïno to BL 2019).

Fig. 3. Comparison of Pelecyogyra from the Fezouata Formation, Morocco, and the Landeyran Formation, Montagne Noire. A. Pelecyogyra fezouataensis Ebbestad and Lefebvre, 2015. Holotype, MHNM.15690.194; Fezouata Formation, Oued Beni Zoli (Z-F5), Anti-Atlas, Morocco. B. Pelecyogyra cf. fezouataensis Ebbestad and Lefebvre, 2015. MNHN.F.A71808 Landeyran Formation, west of Les Sources du Foulon (CS 34), Cessenonsur-Orb, Hérault, southern France. Scale bars: $0.5 \mathrm{~cm}$. 
632

633

634

635

636

637

638

639

640

641

642

643

644

645

646

647

648

649

650

652

651 Indet. cap-shaped mollusc from the site west of Les Sources du Foulon (CS 34). Scale bars: 5

Fig. 4. Pelecyogyra cf. fezouataensis Ebbestad and Lefebvre, 2015. Landeyran Formation, west of Les Sources du Foulon (CS 34), Cessenon-sur-Orb, Hérault, southern France. A-C. MNHN.F.A71806; Dorsal, dorsal oblique and lateral views showing curvature and profile of the whorls. D, E. MNHN.F.A71807; dorsal oblique and dorsal views showing development of aperture. F-H. MNHN.F.A71808; dorsal and detailed views of largest specimen showing protoconch and remnants of the shell. I, J. MNHN.F.A71809; Dorsal view of Pelecyogyra specimen and overview showing the same specimen (right) and two associated specimens of Carcassonnella courtessolei (left) (MNHN.F.A71810, MNHN.F.A71811). Scale bars in A-F, I, J: $5 \mathrm{~mm}$. Scale bars in G, H: $1 \mathrm{~mm}$. (1)

Fig. 5. Associated gastropods and tergomyans in the Landeyran Formation. A. MHNM.

MNHN.F.A71812; Carcassonnella courtessolei found on same slab as Pelecyogyra specimen in Figs 3(B), 4(F). West of Les Sources du Foulon (CS 34). B. MNHN.F.A71813, MNHN.F.A71814; two specimens of Carcassonnella courtessolei from the site west of Les Sources du Foulon (CS 34). Associated with the mollusc indet. in Fig. 5(E, F). C. MNHN.F.A71815; left lateral side of flattened specimen of Thoralispira laevis from Les Rocs Nègres locality (CV 12), Causses-et-Veyran, Hérault, southern France. D. MNHN.F.A71816, MNHN.F.A71817; Thoralispira laevis (left) and Carcassonnella courtessolei from the site west of Les Sources du Foulon (CS 34). E, F. MNHN.F.A71818; $\mathrm{mm}$. 
Figure-01.TIF @ 16,7\% (RGB/8\#) *

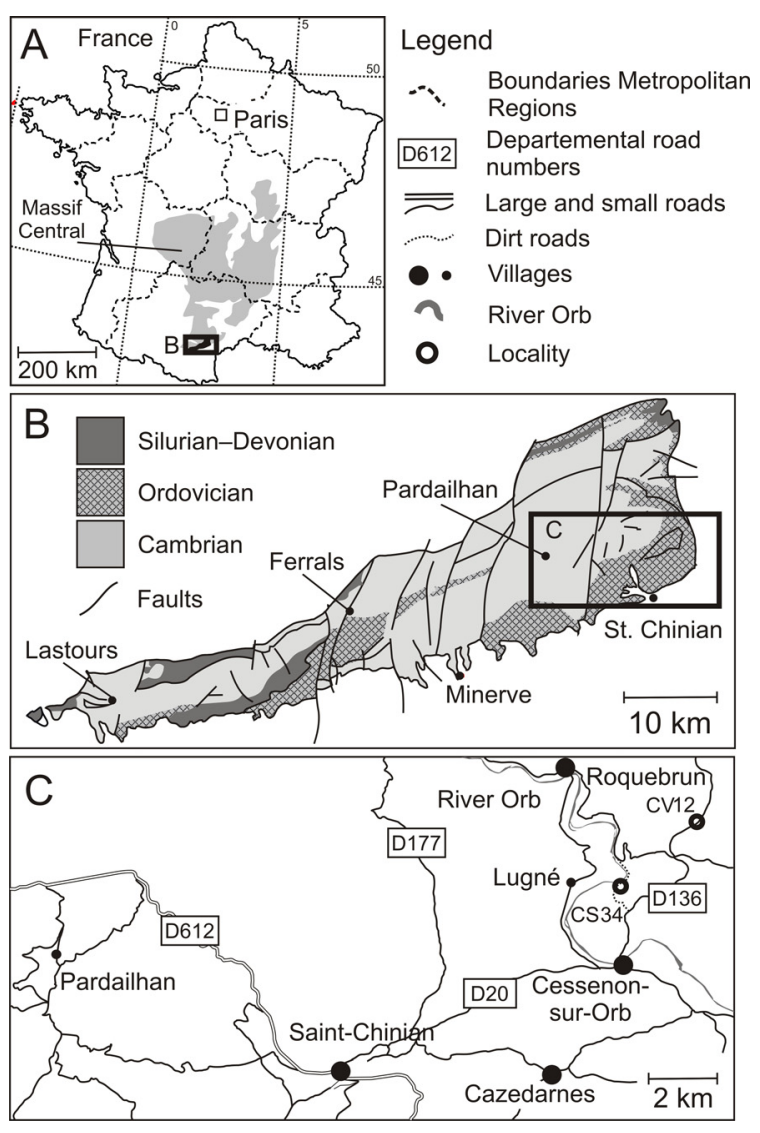


Figure-02.TF @ 12,5\% (RGB/8\#) *

\begin{tabular}{|c|c|c|c|}
\hline \begin{tabular}{|l} 
Periods/ \\
stages
\end{tabular} & \multicolumn{2}{|c|}{ Trilobite zones and subzones } & Formations \\
\hline \multirow{5}{*}{ 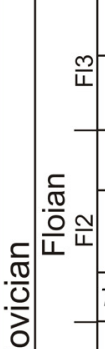 } & Hangch & golithus primitivus & \multirow[b]{2}{*}{ Landeyran } \\
\hline & \multicolumn{2}{|c|}{ Apatokephalus incisus } & \\
\hline & \multicolumn{2}{|c|}{ Neseuretus (N.) arenosus } & Foulon \\
\hline & \multicolumn{2}{|c|}{ Colpocoryphe maynardensis } & Cluse de l'Orb \\
\hline & \multicolumn{2}{|c|}{ Taihungshania shui landeyranensis } & Setso \\
\hline 음 & T. miqueli & $\begin{array}{c}\text { T. miqueli acme } \\
\text { Asaphelina barroisi }\end{array}$ & La Maurerie \\
\hline & & berardi and T. miqueli & \\
\hline \multirow{3}{*}{ 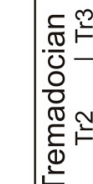 } & \multicolumn{2}{|c|}{ Euloma filacovi } & Saint-Chinian \\
\hline & \multicolumn{2}{|c|}{ Shumardia (C.) pusilla } & Mounio \\
\hline & \multicolumn{2}{|c|}{ Proteuloma geinitzi } & La Dentelle \\
\hline
\end{tabular}

Montagne Noire, France

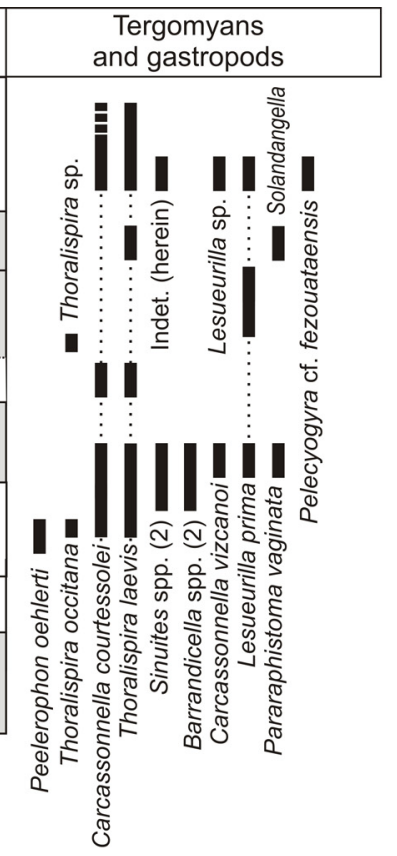


Figure 3

Figure-03.tif @ 25\% (Gray/8) *
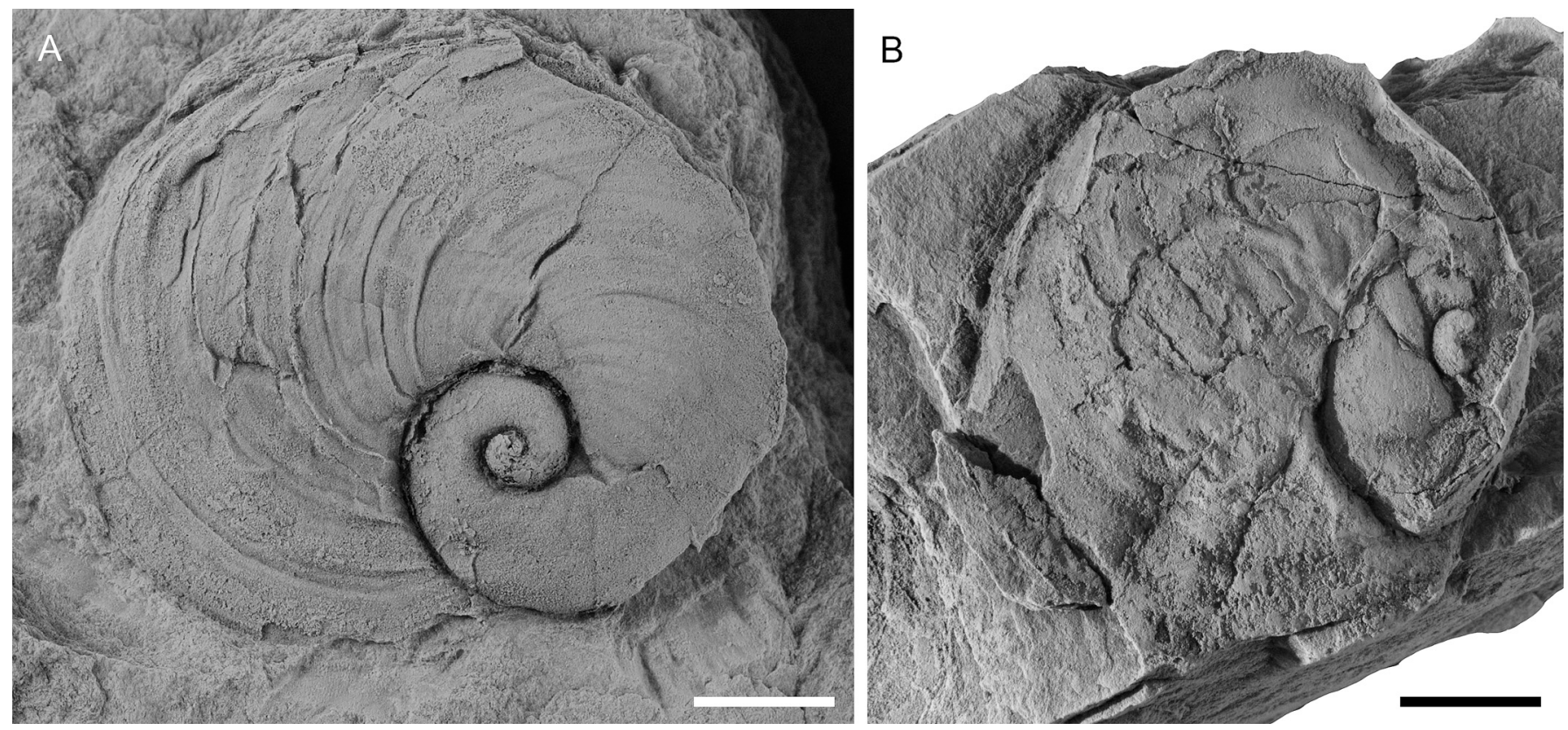
Figure-04.tif

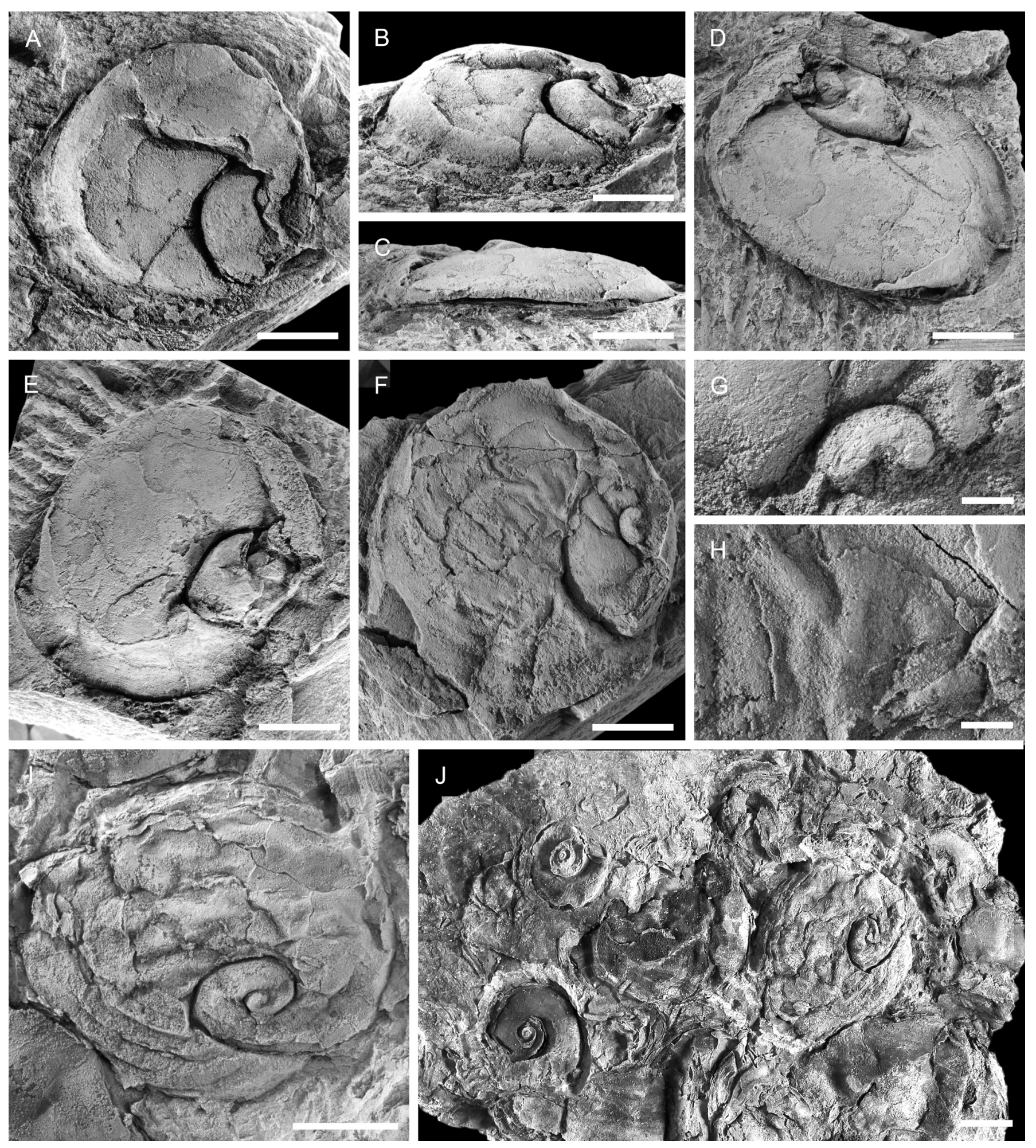


Figure-05.tif @ 25\% (Background, Gray/8) *
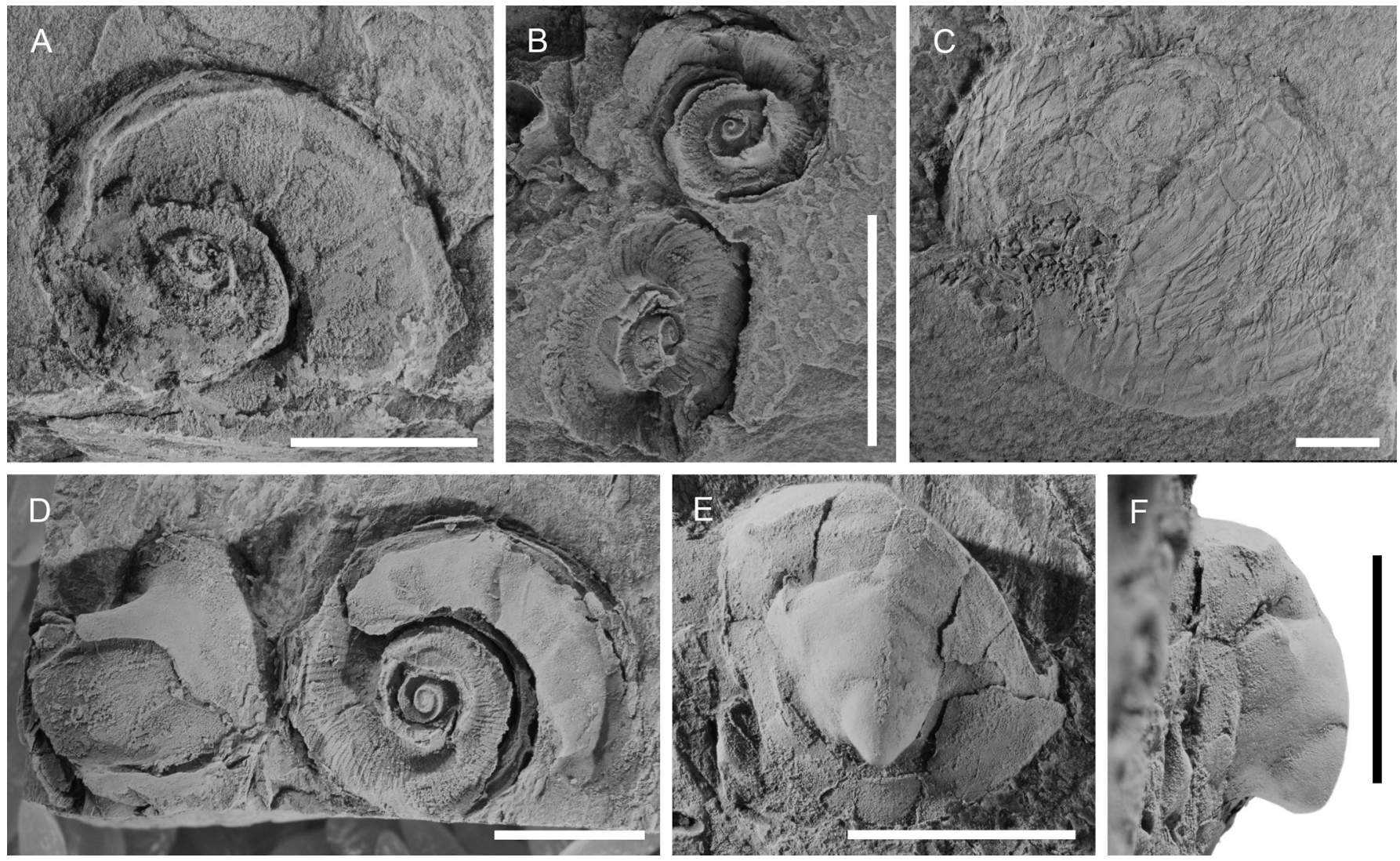